\title{
Article \\ Contributing to Understand the Crosstalk between Brain and Periphery in Methylmercury Intoxication: Neurotoxicity and Extracellular Vesicles
}

\author{
Gabriela de Paula Arrifano 1,2 (D), Marcus Augusto-Oliveira 1,2 ${ }^{(D)}$, Megan Sealey-Bright ${ }^{2}$, Jaezah Zainal ${ }^{2}$, \\ Luciana Imbiriba $^{1}$, Luanna Melo Pereira Fernandes ${ }^{3}$, Cristiane Socorro Ferraz Maia ${ }^{3}$, Daniel Anthony ${ }^{2, *}$ (D) \\ and Maria Elena Crespo-Lopez ${ }^{1, * \mathbb{D}}$
}

1 Laboratório de Farmacologia Molecular, Instituto de Ciências Biológicas, Universidade Federal do Pará, Belém 66075-110, Brazil; arrifanogabriela@gmail.com (G.d.P.A.); marcusoliveira@globo.com (M.A.-O.); imbiriba.luciana@gmail.com (L.I.)

2 Department of Pharmacology, University of Oxford, Oxford OX1 3QT, UK; MBright@rosetreestrust.co.uk (M.S.-B.); jaezah.zainalazman@pharm.ox.ac.uk (J.Z.)

3 Laboratory of Pharmacology of Inflammation and Behavior, Faculty of Pharmacy, Institute of Health Science, Federal University of Pará, Belém 66075-110, Brazil; luannafe@hotmail.com (L.M.P.F.); crismaia@ufpa.br (C.S.F.M.)

check for updates

Citation: Arrifano, G.d.P.; Augusto-Oliveira, M.; Sealey-Bright, M.; Zainal, J.; Imbiriba, L.; Fernandes, L.M.P.; Maia, C.S.F.; Anthony, D.; Crespo-Lopez, M.E. Contributing to Understand the Crosstalk between Brain and Periphery in

Methylmercury Intoxication:

Neurotoxicity and Extracellular Vesicles. Int. J. Mol. Sci. 2021, 22, 10855. https://doi.org/10.3390/ ijms221910855

Academic Editor: Guido R.M.M. Haenen

Received: 30 August 2021 Accepted: 5 October 2021 Published: 7 October 2021

Publisher's Note: MDPI stays neutral with regard to jurisdictional claims in published maps and institutional affiliations.

Copyright: (c) 2021 by the authors. Licensee MDPI, Basel, Switzerland. This article is an open access article distributed under the terms and conditions of the Creative Commons Attribution (CC BY) license (https:/ / creativecommons.org/licenses/by/ $4.0 /)$.
* Correspondence: daniel.anthony@pharm.ox.ac.uk (D.A.); maria.elena.crespo.lopez@gmail.com (M.E.C.-L.)
Abstract: Human exposure to methylmercury ( $\mathrm{MeHg}$ ) is currently high in regions such as the Amazon. Understanding the molecular changes associated with $\mathrm{MeHg}$-induced neurotoxicity and the crosstalk with the periphery is essential to support early diagnoses. This work aimed to evaluate cellular and molecular changes associated with behavioral alterations in $\mathrm{MeHg}$ acute exposure and the possible changes in extracellular vesicles (EVs) number and S100 $\beta$ content. Adults male Wistar rats were orally treated with $5 \mathrm{mg} / \mathrm{kg}$ for four days. Behavioral performance, molecular and histological changes in the cerebellum, and plasma EVs were assessed. MeHg-intoxicated animals performed significantly worse in behavioral tests. $\mathrm{MeHg}$ increased the number of GFAP+ cells and GFAP and S100 $\beta$ mRNA expression in the cerebellum but no change in NeuN+ or IBA-1+ cells number was detected. The number of exosomes isolated from plasma were decreased by the metal. S100B mRNA was detected in circulating plasma EVs cargo in MeHg exposure. Though preliminary, our results suggest astrocytic reactivity is displaying a protective role once there was no neuronal death. Interestingly, the reduction in exosomes number could be a new mechanism associated with $\mathrm{MeHg}$-induced neurotoxicity and plasma EVs could represent a source of future biomarkers in $\mathrm{MeHg}$ intoxication.

Keywords: exosomes; mercury; MeHg; exposure; pollution; pollutant; CNS; S100b; real time; qPCR

\section{Introduction}

Mercury is included in the top ten most dangerous pollutants [1], and while there is a global commitment to reduce its emissions into the environment (Minamata Conventionhttps: / / www.mercuryconvention.org/, accessed on 4 October 2021), levels continue to increase [2]. This metal is ubiquitous and once it reaches the watershed it can be biotransformed by methanogenic bacteria into methylmercury (MeHg). In the latter form, it suffers bioaccumulation and biomagnification through the food chain, which represents the main route of human exposure by the ingestion of contaminated fish [2]. Human exposure to $\mathrm{MeHg}$, the most toxic form of mercury, is currently high in regions such as the Amazon $[3,4]$ due to the high consumption of piscivorous fish (with the highest levels of the metal [5] in the diet of traditional populations [6]).

The central nervous system (CNS) is the principal target for MeHg toxicity, which can give rise to psychomotor alterations, damage to the visual system, and tremors, 
among other neurological symptoms $[7,8]$. The cerebellum is particularly susceptible to $\mathrm{MeHg}[9,10]$. Indeed, a hallmark of $\mathrm{MeHg}$ intoxication is cerebellar ataxia owing to the dysfunction of granule cell neurons [11]. MeHg also affects microglia (the main arm of defense system of the CNS [12]) and astrocytes (which regulate several critical events including synapse formation, plasticity, and elimination ultimately regulating animal behavior [13]) [14,15]. Noteworthy, the precise role performed by astrocytes in $\mathrm{MeHg}$ intoxication is currently under intense debate [15].

An accurate diagnosis of mercury intoxication can be very problematic as it is associated with many symptoms [16]. Furthermore, as a consequence of the influence of genetic susceptibility, dose, and time of exposure, it is often difficult to find a direct correlation between mercury levels (i.e., exposure) and symptoms [16-18]. Thus, there is an urgent need for the development of peripheral biomarkers to support the early diagnosis of mercuryinduced neurotoxicity $[19,20]$. Recently, both protein and mRNA of S100 calcium-binding protein B (S100 $\beta)$ were proposed as blood biomarker of mercury intoxication $[17,18]$. The increased release of $S 100 \beta$ by glia is a well-documented response to acute and chronic brain pathology [21]. The possibility of measuring peripheral changes of this biomarker, directly associated to its changes in CNS, would allow for earlier diagnosis and intervention.

In this context, there is an urgent need to better understand the crosstalk between the brain and the periphery in MeHg-induced neurotoxicity. In recent years, extracellular vesicles (EVs) have emerged as important elements in cell communication and as potential source of biomarkers for disease [22,23]. EVs are small bi-layer-enclosed vesicles (nano to microsized), which are released for intercellular communication locally and between organs $[24,25]$. There are three main subtypes of EVs: (1) exosomes, which are the smallest EVs (40-100 nm in diameter); (2) microvesicles (50-1000 nm in diameter); and (3) apoptotic bodies (500-2000 $\mathrm{nm}$ in diameter) [24,25]. EVs are known to cross the blood brain barrier $[22,25]$ and to have a role in the crosstalk between brain and periphery. For example, CNS-derived plasma exosomes in living humans have been found to be altered in preclinical Alzheimer disease studies [26-28]. As a consequence, changes in the peripheral EVs population also afford a potential biomarker for evaluating $\mathrm{MeHg}$ toxicity.

Here we sought to evaluate how the EVs populations is altered and how S100 $\beta$ levels related to neural and behavioral alterations in $\mathrm{MeHg}$ acute exposure.

\section{Results}

\section{1. $\mathrm{MeHg}$ Induced Motor Impairment}

To test for neural and behavioral changes, rats were first treated with $\mathrm{MeHg}(5 \mathrm{mg} / \mathrm{kg}$, via oral) for four consecutive days. Behavioral functions such as balance and coordination were tested $24 \mathrm{~h}$ after the last treatment. The animals underwent open field and rotarod tests.

Animals treated with $\mathrm{MeHg}$ showed significant decrease in both number of rearings registered in the open field test (Figure 1B), and latency time to the first fall in the latest stage of the rotarod test when given at the highest dose, as compared to control animals (Figure 1C), suggestive of $\mathrm{MeHg}$ toxicity. 
A

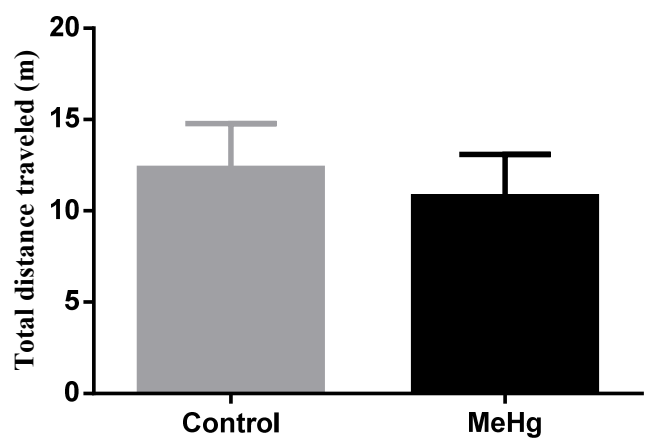

B

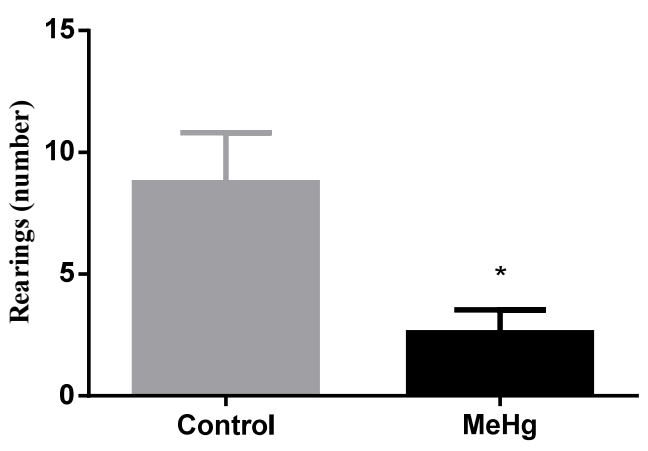

C

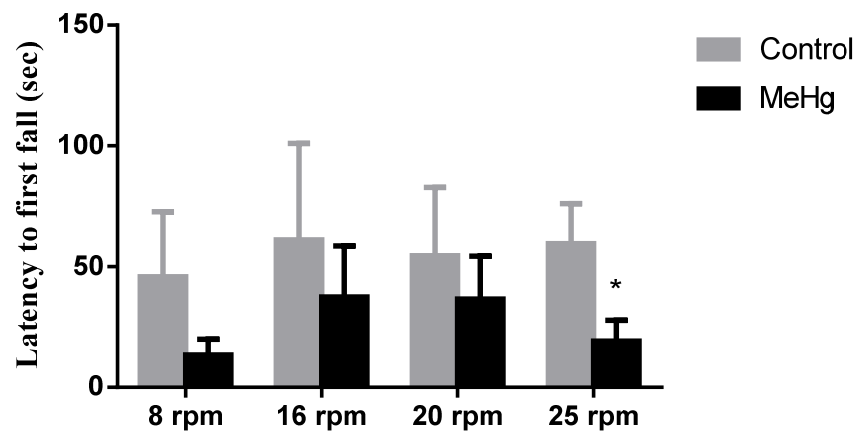

Figure 1. Effects of methylmercury (MeHg) in motor performance. Total distance walked (A) and number of rearings (B) registered in the open field test, and latency time to the first fall in the rotarod test $(\mathbf{C})$ were analyzed in rats orally exposed to water (Control) or $\mathrm{MeHg} 5 \mathrm{mg} / \mathrm{kg}(\mathrm{MeHg}$ ) for four consecutive days. Behavioral tests were performed $24 \mathrm{~h}$ after the last dose of treatment. Results are expressed as mean \pm SEM. $n=4-5$ per group. Student $t$ test, ${ }^{*} p<0.05$ vs. control.

\section{2. $\mathrm{MeHg}$ Induced Histological Changes}

The animals were sacrificed $24 \mathrm{~h}$ after the treatment, perfused and the brains were fixed for histology. We wanted to assess whether MeHg toxicity affected the number of cells in the cerebellum as a marker of damage. Immunohistochemistry for neuronal nuclei $(\mathrm{NeuN})$, ionized calcium binding adaptor molecule 1 (IbaI) or glial fibrillary acidic protein (GFAP) was used to visualize neurons, microglia and astrocytes, respectively.

In fact, $\mathrm{MeHg}$ treatment appeared to induce a small but significant increase in the number of GFAP+ cells (Figure 2C) but no change in NeuN+ or IbaI+ cells (Figure 2A,B), suggesting astroglial reactivity. 


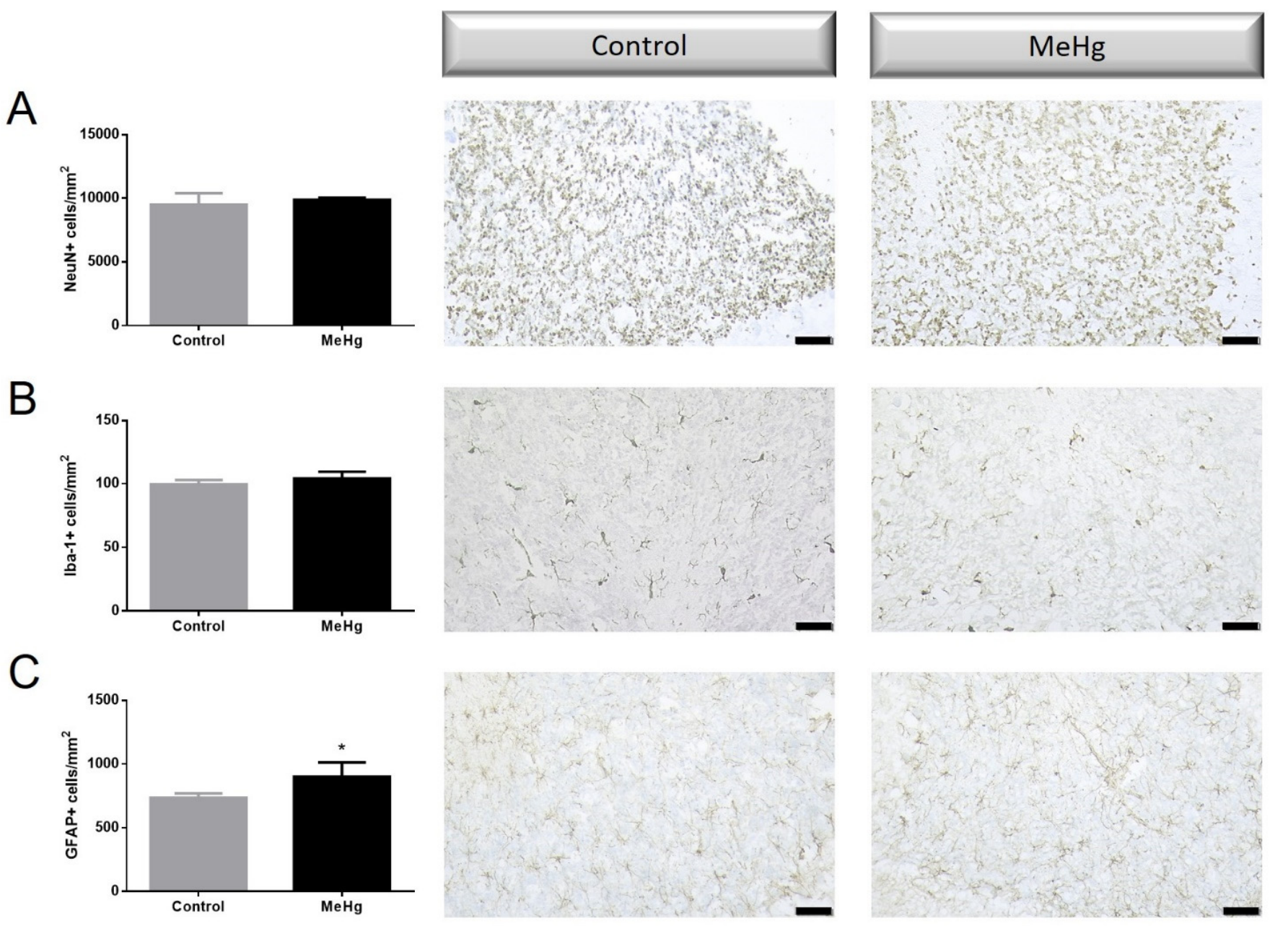

Figure 2. Effects of methylmercury (MeHg) in neurons, microglia and astrocytes in cerebellum. Quantitation of immunostaining cells (graphics on the left) and representative photomicrographs (center and right) of the cerebellum of rats orally exposed to water (Control) or MeHg $5 \mathrm{mg} / \mathrm{kg}$ (MeHg) for four consecutive days: (A) neurons (positive cells for NeuN marker, NeuN+); (B) microglial cells (positive for Iba-1 marker, Iba-1+); and (C) astrocytes (positive cells for GFAP marker, GFAP+). Immunohistochemistry was performed $24 \mathrm{~h}$ after the last dose of treatment. Results are expressed as mean $\pm \mathrm{SEM}$. $n=3-4$ per group. Student $t$ test, ${ }^{*} p<0.05$ vs. control. Scale bar $=50 \mu \mathrm{m}$.

\subsection{MeHg Induced Changes in Neuronal and Astrocytic Reactivity Molecular Markers}

To understand the effect that MeHg toxicity has on neuronal and astrocytic cells in the cerebellum, an array of markers was probed using RT-qPCR. The neuronal disturbance was assessed through mRNA expression of GLUT1R subunit of AMPA receptor (GRIA1) and neuronal specific enolase (ENO2) and the astrocytic reactivity was evaluated through mRNA expression of GFAP and S100 $\beta$. Though preliminary, we found that MeHg treatment induced GRIA1, ENO2, GFAP and S100 $\beta$ gene expression in the cerebellum (Figure 3) suggesting both neuronal injury and astrocyte reactivity at molecular levels. 

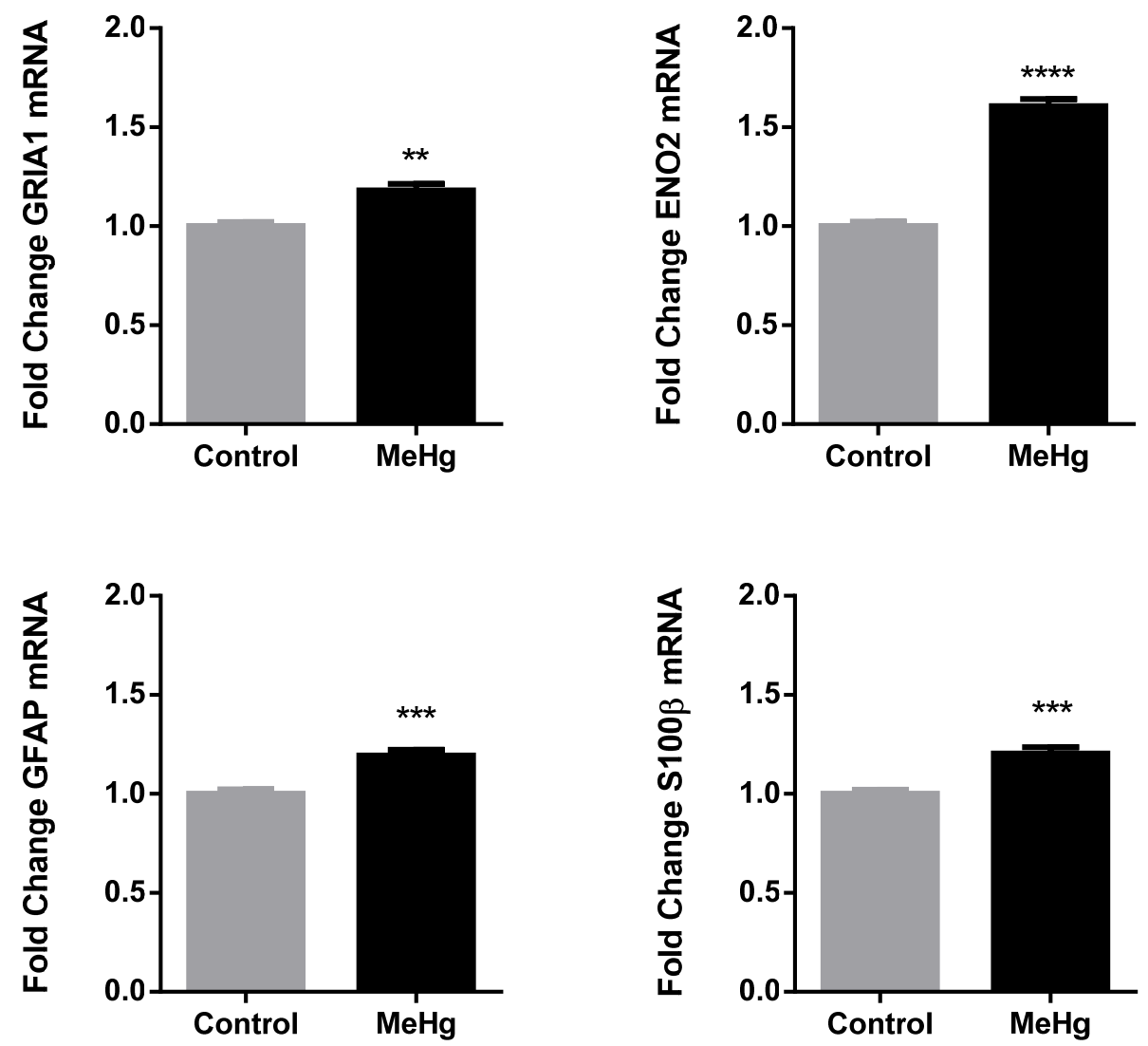

Figure 3. Effects of methylmercury $(\mathrm{MeHg})$ in gene expression in the cerebellum. Expression of GRIA1, ENO2, GFAP and $\mathrm{S} 100 \beta$ genes in the cerebellum of rats exposed to water (Control) or $\mathrm{MeHg}$ $5 \mathrm{mg} / \mathrm{kg}(\mathrm{MeHg}$ ) for four consecutive days were assessed by RT-qPCR $24 \mathrm{~h}$ after the last dose of treatment. Results are expressed as mean \pm SEM. $n=4-5$ per group. Student $t$ test ${ }^{* *} p<0.01$; *** $p<0.0011^{* * * *} p<0.0001$ vs. control.

\subsection{Plasma Extracellular Vesicles}

As EVs have been found to contain biomarkers for other conditions, the number of EVs was assessed here using nanoparticle tracking analysis (NTA) and the EVs cargo was determined by RT-qPCR. We found that MeHg treatment induced no change in the overall total number of EVs (Figure $4 \mathrm{~A}$ ) however the treatment did result in significant lower number of smaller EVs (45, 75 and $105 \mathrm{~nm}$ ) isolated from plasma (Figure 4B). 


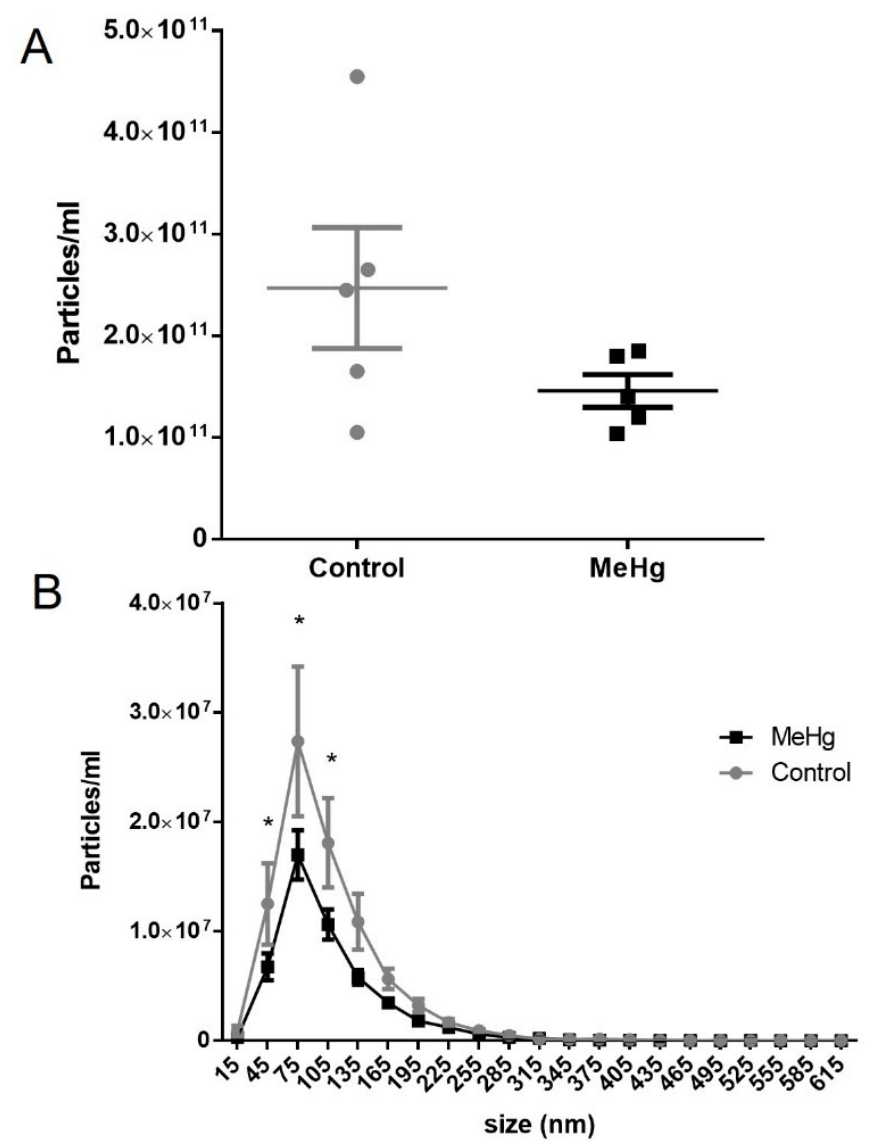

C

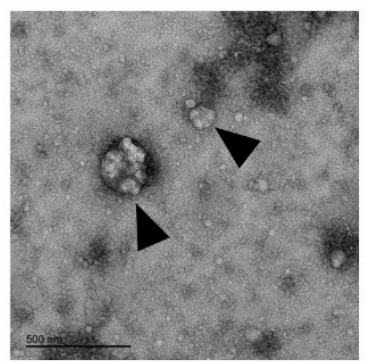

D

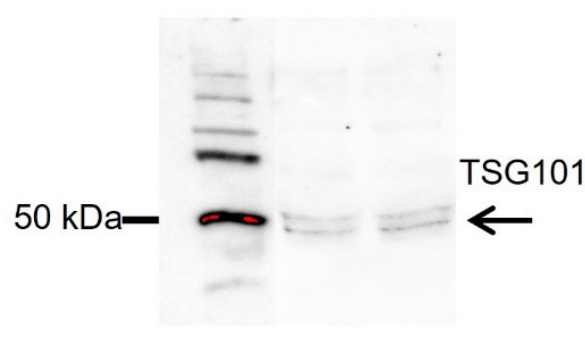

Figure 4. Effects of methylmercury (MeHg) in circulating plasma extracellular vesicles (EVs). Rats were orally exposed to water (Control) or $\mathrm{MeHg} 5 \mathrm{mg} / \mathrm{kg}$ (MeHg) for four consecutive days and EVs were isolated from plasma: (A) total number of EVs (each dot representing each treated animal); (B) number of smaller EVs (45, 75, and $105 \mathrm{~nm}$ ); (C) representative electron micrograph (scale bar of $500 \mu \mathrm{m}$ ) showing the detected EVs (black arrow head); and (D) western blot showing that EVs were immunopositive for the TSG101 (black arrow), a protein marker of EVs. EVs isolation was performed $24 \mathrm{~h}$ after the last dose of treatment. Results are expressed as mean \pm SEM. $n=4-5$ per group. Student $t$ test (A) and two-way ANOVA (B), ${ }^{*} p<0.05$ vs. control.

Images acquired by transmission electron microscopy revealed the presence of extracellular vesicles isolated from plasma (Figure 4C). Western blotting showed that EVs were immunopositive for the tumour susceptibility gene 101 protein (TSG101), a protein marker of EVs (Figure 4D).

Next, in order to investigate whether circulating plasma EVs carried $S 100 \beta$ mRNA, we extracted RNA from the EVs fraction and probed to S100 $\beta$ using RT-qPCR. Thus, in this preliminary approach, we detected the $S 100 \beta$ mRNA inside of the EVs, although the possible difference between groups ( $\mathrm{MeHg}$ vs. control) did not reach statistical significance (Figure 5). 


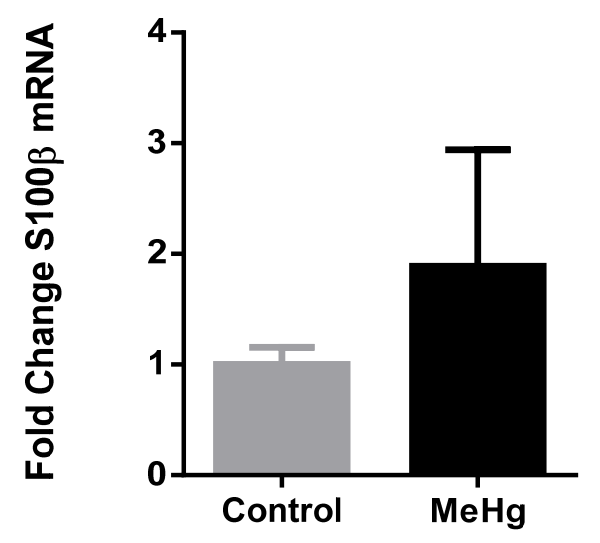

Figure 5. S100 $\beta$ mRNA in circulating plasma EVs cargo. Rats exposed to $\mathrm{MeHg} 5 \mathrm{mg} / \mathrm{kg}$ for four consecutive days presented no significant change in S100 $\beta$ mRNA in EVs cargo. Results are expressed as mean \pm SEM. $n=4-5$ per group. Student $t$ test $p>0.05$.

\section{Discussion}

In the present manuscript we assessed molecular and histological changes in the cerebellum in an acute MeHg-intoxication model in rats. This is the first paper which attempts to understand the crosstalk between the brain and periphery in a model of $\mathrm{MeHg}$ brain injury.

An acute exposure model by oral gavage was used to test the methylmercury-induced neurotoxicity. High levels of human exposure are usually found in regions such as the Amazon, mainly due to the consumption of contaminated fish [2,5]. The model used in our work, to simulate the most common pathway (oral) of human exposure to $\mathrm{MeHg}$, has previously been used to show gastrointestinal changes in aquaporines' gene expression, as a new mechanism of absorption of $\mathrm{MeHg}$ in the gut [29]. Thus, this dose is able to produce significant changes at molecular level, allowing the understanding of early stage of $\mathrm{MeHg}$ intoxication. Here we showed that $\mathrm{MeHg}$ exposure produced motor impairment once animals treated with the metal performed significantly worse in vertical exploitation on the open field as well as in the last stage of rotarod test (Figure 1). Such reduced vertical exploration has previously been observed even with $\mathrm{MeHg}$ subtoxic-dose exposure [30]. However, although an open field test has already been used to evaluate motor activity in mercury intoxication, previous data showed that it may not be the most sensitive test, probably since the performance is mainly related to the motor cortex $[31,32]$. Rotarod is well-documented to be better at evaluating neurobehavioral alterations caused by $\mathrm{MeHg}$ [31,33-35]. Indeed, although we found no change in the total distance travelled in the open field test, we did find a significantly decreased latency to the first fall in the rotarod test at $25 \mathrm{rpm}$. These results strongly suggest that the brain injury is related to damage in the cerebellum.

It has been reported that the cerebellar region is severely injured in rat models of $\mathrm{MeHg}$ intoxication [36,37]. Our results demonstrated that $\mathrm{MeHg}$ increased the number of GFAP+ cells (Figure 2) as well as mRNA expression of GFAP and S100 $\beta$ (Figure 3 ) in the cerebellum, pointing to astrocytic reactivity. Moreover, neuronal disturbance was detected by the increased mRNA expression of GRIA1 and ENO2 in this brain area (Figure 3). However, $\mathrm{MeHg}$ induced no significant changes in number of neurons (NeuN+cells) or microglia (IBA-1+ cells) in the cerebellum (Figure 2), in our model, suggesting that the increase in ENO2 (neuronal injury) and GRIA1 (indirectly indicative of glutamatergic imbalance) mRNA would not be sufficient to culminate in excitogenic cell death only $24 \mathrm{~h}$ after last dose of treatment. However, this acute exposure was enough to lead to astrocytic reactivity, as shown by the significant increase in number of GFAP positive cells (Figure 2) and increased expression of GFAP and S100 $\beta$ mRNA (Figure 3).

Our data reinforces the involvement of glutamatergic toxicity, a well-documented mechanism of MeHg-induced neurotoxicity [15,34,38]. MeHg enhances spontaneous glu- 
tamate release from neurons and specifically inhibits the astrocytic glutamate uptake resulting in excessive concentrations of glutamate in the synaptic cleft $[15,39]$. Previously, the mercury-induced glutamatergic excitotoxicity was shown to be mediated through $\mathrm{N}$-methyl-D-Aspartate receptors (NMDA) in vitro [40]. However, functionally, the most important glutamate receptors to mediate fast excitatory transmission are AMPA receptors (AMPARs) [41]. The increased expression of GRIA1 mRNA in the cerebellum observed in our results (Figure 3), supports the glutamatergic imbalance caused by $\mathrm{MeHg}$, as it would be expected. The long-term consequences of this increased expression of GRIA1 mRNA would eventually include the increased number and, thus, dysregulation of AMPARs with implications in several pathological states and mental health [42]. Recently, a role for MeHg-AMPA receptors interaction was suggested to be involved in amyotrophic lateral sclerosis [43,44]. Moreover, S100 $\beta$ release is increased upon exposure of astrocytes to glutamate [45], also supporting the hypothesis that astrocytic damage is related to an excess of glutamate in the synaptic cleft.

After acute brain injury, ENO2 gene expression was increased in the brain [46]. ENO2 is a glycolytic isoenzyme expressed exclusively in neurons, and some studies have raised the possibility that this enzyme could be associated with neuronal damage (reviewed by $[47,48])$. Our data showed a significant increased expression of ENO2 in the cerebellum possibly indicating neuronal injury (Figure 3).

Furthermore, our results have additional importance in the translational context. Increased levels of GRIA1 and ENO2 proteins have already been detected in the blood of children exposed to elemental mercury, supporting their value as diagnostic markers [17]. However, this is the first time that both markers have been shown to be altered in brain under MeHg-neurotoxicity.

Following neuronal disfunction, a compensatory response is exerted by astrocytes to protect neurons against death [49]. Astrogliosis is a process believed to have several functions in the brain. Depending on the scenario, astrocytic reactivity could be neuroprotective, leading to repair and return to homeostasis, or detrimental, relating to the inhibition of neuronal axon outgrowth, for instance [50]. Whether astrocytes display a beneficial role or a detrimental one under MeHg-induced neurotoxicity remains controversial (reviewed by [15]). The astrogliosis detected in the present work was assessed using GFAP and S100 $\beta$ (Figure 3), considered the best markers (sensitive and reliable) for detecting astrocytic reactivity following CNS injury [51-53]. It is worth noting that the mRNA expression of these markers has been shown to be even more useful for diagnosis than the proteins due to easier conservation, especially for isolated/remote populations [18]. Circulating S100 $\beta$ mRNA has been recently showed to be associated to MeHg exposure in humans [18]. Another interesting fact with valuable meaning in the translational context is that significant S100 $\beta$ mRNA expression was associated with behavioral changes, but it was detected before any significant neuronal death. This supports the use of $S 100 \beta$ as a marker for early diagnosis to prevent the worst consequences of $\mathrm{MeHg}$ intoxication.

Considering neuronal death is secondary to disturbances in astrocytes [54], and the animals treated with $\mathrm{MeHg}$ did not present significant neuronal death (no change in NeuN+ cells number), our data suggest that astrocytes are playing a neuroprotective role in this window of mercury exposure, as recently hypothesized [15]. A growing body of evidence has shown that astrocytes can protect neurons against $\mathrm{MeHg}$-induced neurotoxicity from several pathways (reviewed by [15]). It is hypothesized that in the early stages of $\mathrm{MeHg}$ exposure, astrocytes, along with other glial cells, perform cellular and molecular responses to restrict CNS injury. However, in later stages of $\mathrm{MeHg}$ exposure, once astrocytes lose their functions or gain maladaptive ones, neuronal damage caused by $\mathrm{MeHg}$ would be exacerbated [15].

In CNS injury, signals from the brain are sent to the periphery thorough several mechanism, particularly EVs, which are considered a mode of intercellular communication $[22,23,25]$. Following brain acute trauma, the circulating number of EVs in the plasma increases and the EVs shed from brain cells are able to incite sick behavior in naïve 
mice $[55,56]$. As far as we know, there is no data on how MeHg affects EV homeostasis. In this sense, our seminal work shows that acute exposure to $\mathrm{MeHg}$ induced no change in the total number of particles per $\mathrm{ml}$ after $24 \mathrm{~h}$ of last dose administered (Figure $4 \mathrm{~A}$ ). However, a significant decrease in the number of exosomes (45-105 nm) (Figure 4B) can be already detected at this exposure time window. It is possible that this reduction in exosomes is a novel mechanism of $\mathrm{MeHg}$ - induced neurotoxicity, since in the CNS exosomes have been found to play a role in tissue repair and regeneration (reviewed by [57]).

Considering EVs cargo is a potential source of biomarkers [25-28] and S100 $\beta$ mRNA was recently shown as a strong candidate biomarker of mercury-related neurotoxicity in humans [18], we investigated whether this marker is contained in EVs cargo isolated from plasma. In this work we demonstrated for the first time the presence of S100 $\beta$ mRNA in EVs plasma cargo (Figure 5). This preliminary finding is even more relevant for future clinical applications if we consider the previous work which has shown S100 $\beta$ protein in CSF EV fractions isolated from patients with cognitive impairment [58]. Although the possible difference due to $\mathrm{MeHg}$ intoxication in S100 $\beta$ mRNA in EVs plasma cargo did not reach statistical significance, looking at Figure 5, it would be premature to assume that $\mathrm{MeHg}$ does not have any influence. Although the increased expression of $\mathrm{S} 100 \beta$ mRNA would be in line with what we know (previous findings published so far), future studies including a higher sample size are necessary to clarify our results, since we here demonstrated that it is possible to detect $\mathrm{S} 100 \beta \mathrm{mRNA}$ in circulating plasma EVs, a known biomarker of CNS early injury. This would corroborate previous data showing increased levels of S100 $\beta$ protein in cerebrospinal fluid and serum after brain damage [59-61] and mercury exposure [17,18,62], even before the onset of clinical symptoms [17]. The EV content in MeHg exposure scenario could be used as a circulating library for the detection of CNS damage, and this work was the first to approach this idea. Moreover, the RNA contained in EVs is protected against RNase degradation and it is stable under a range of temperature and $\mathrm{pH}$ conditions, even with prolonged storage and multiple freezethaws [63], making it an excellent alternative for detecting neurotoxicity in isolated/remote populations or locations with limited infrastructure. Currently, South America and SubSaharan Africa are responsible for more than one third of the global emissions of mercury, and populations in these regions are among the most exposed populations in the world (UNEP), reinforcing the importance of the research for the development of peripheral biomarkers for early diagnosis of mercury-induced neurotoxicity that are adequate for the study of these populations [20]

\section{Materials and Methods}

\subsection{Animals Treatment}

Twenty-eight male adult Wistar rats (11 weeks old, 220-290 g) were maintained with controlled light and temperature $\left(22 \pm 2{ }^{\circ} \mathrm{C} ; 12 \mathrm{~h}\right.$ light/dark cycle) with food and water ad libitum. The animals were allowed to acclimatize for one week and were properly manipulated to reduce stress, and all experimental procedures were carried out in accordance with the NIH Guide for the Care and Use of Laboratory Animals after approved by the Committee for Ethics in Experimental Research with Animals of the Universidade Federal do Pará (CEUA 8343070518).

Animals were randomly allocated into two groups (Control and $\mathrm{MeHg}$ ) and were treated by oral gastric gavage once a day with water or methylmercury chloride (diluted in water, final dose of $5 \mathrm{mg} / \mathrm{kg}$ per body weight)(Figure 6) [29]. 


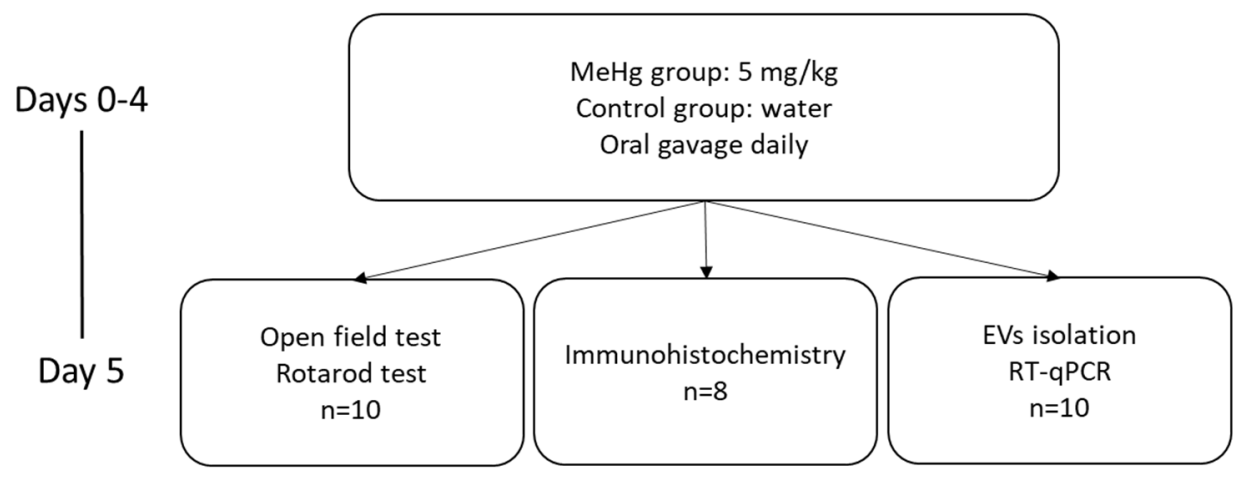

Figure 6. Experimental design.

\subsection{Samples Collection}

Twenty-four hours after the last treatment, the animals were anesthetized with $40 \mathrm{mg} / \mathrm{kg}$ of sodium thiopental, and sample collection was performed.

A set of animals (eight animals, four per group) were transcardially perfused with ice-cold saline containing heparin $(20 \mu \mathrm{L} / 100 \mathrm{~mL})$, followed by $4 \%$ paraformaldehyde (PFA) in $0.1 \mathrm{M}$ phosphate-buffered saline (PBS) (Bento-Torres et al., 2017). Brains were rapidly extracted and post-fixed in $4 \%$ PFA, followed by cryoprotection in a $30 \%$ sucrose solution, embedded in OCT (Thermo Fisher Scientific, Abingdon, UK) and frozen at $-80{ }^{\circ} \mathrm{C}$ until use [56].

A different set of animals ( 10 animals, 5 per group) was used for blood and cerebella collection. Once anesthetized, blood samples were collected via cardiac puncture in EDTA tubes and cerebella were immediately dissected, being snap-frozen in dry ice and stored in $-80{ }^{\circ} \mathrm{C}$ for posterior analysis.

\subsection{Behavioral Tests}

Twenty-four hours after the last intoxication, a set of animals (10 animals, 5 per group) was conducted to the room experiment and maintained for $1 \mathrm{~h}$ of acclimatization with light (12 lux) and noise control. All behavioral tests were carried out from 8:00 a.m. until 18:00 p.m. to avoid circadian cycle alteration.

\subsubsection{Open Field Test}

Open field test consisted of placing the animal on the center of an acrylic black arena $(100 \times 100 \times 45 \mathrm{~cm})$ and filmed for $5 \mathrm{~min}$. Both vertical (rearing) and horizontal (distance travelled) spontaneous ambulation of the animal were recorded [64]. Distance travelled by the animals was analyzed by the ANY-mazeTM (Stoelting, Wood Dale, IL, USA) software. The rearing was manually registered and the researcher was blinded to treatment group while assessing it.

\subsubsection{Rotarod Test}

After the open field test, animals were submitted to rotarod test. The equipment consists of an elevated rotation rod motor controlled (Insight, Ribeirão Preto, Brazil), which allows for the rotation velocity to be increased, ranging from 8 rotations per minute (rpm) to $25 \mathrm{rpm}$, to intensify the difficulty of the test. Briefly, animals were placed on the rotating bar immediately after the velocity of the trial was reached. The trials of the test were at 8 , 16,20 , and $25 \mathrm{rpm}$, with an intertrial interval of $60 \mathrm{~s}$. The cut-off point for each trial was $180 \mathrm{~s}$. The latency of the first fall at each session was recorded by a researcher blinded to treatment group (adapted from [30]).

\subsection{Platelet-Free Plasma Obtention}

Blood samples in EDTA tubes were sat for $30 \mathrm{~min}$ at room temperature. After that, samples went through two subsequent centrifugations steps of $2500 \mathrm{~g}$ for $15 \mathrm{~min}$ at room 
temperature [65] using a clean plastic tube for the second centrifugation step. Samples were aliquoted and stored in $-80^{\circ} \mathrm{C}$ for subsequent analysis.

\subsection{Immunohistochemistry}

From fixed brains embedded in OCT, $10 \mu \mathrm{m}$ thick sections were cut using a cryostat at $20{ }^{\circ} \mathrm{C}$ (Leica Microsystems, Milton Keynes, UK). Sagital serial sections were collected with $0.1 \mathrm{M}$ phosphate buffer on gelatinised slides, tissue was allowed to dry overnight and stored at $-20^{\circ} \mathrm{C}$. Immunohistochemistry was performed using the avidin-biotinperoxidase method in a Shandon Sequenza ${ }^{\circledR}$ staining system (Thermo Fisher Scientific, Abingdon, UK). Alternate serial sections were immunolabeled with a polyclonal antibody against neuronal nucleus to detect adult neurons (anti-NeuN, 1:2000, Abcam, Cambridge, UK), Iba-1 to detect microglia / macrophages (anti-Iba-1; 1:2000, Abcam, Cambridge, UK) and glial fibrillary acidic protein (GFAP) to detect reactive astrocyte (anti-GFAP; 1:700, Dako, Cambridge, UK). All slides were counterstained in a $0.5 \%$ cresyl violet acetate solution ( $\mathrm{pH}$ 3.3). Slides were dehydrated by serial increasing concentrations of alcohol, cleared in xylene and mounted on coverslips with DPX (Fisher Scientific, Loughborough, UK). All slides were randomised and blinded until analysis was complete. Images were taken of the cerebellum with Basler Microscope Software using a light microscope (Leitz Dialux 20) coupled with Microscope Camera 2.0 MP (Basler, High Wycombe, UK). The number of positive cells for each marker was determined using ImageJ (Software version $1.52 \mathrm{p}$, Bethesda, MD, USA).

\subsection{Relative Quantification of Gene Expression in Brain Areas}

Total RNA was extracted from the cerebellum using the QIAshredder and RNeasy Mini Kit (Qiagen, Manchester, UK) as per manufacturer's instructions. Eluted RNA was quantified using a NanoDrop 1000 spectrophotometer (Thermo Fisher Scientific, Abingdon, UK), RNA was considered acceptable for cDNA conversion if 260/280 and 260/230 ratios were $>2$. One thousand ng whole RNA was converted to cDNA using the HighCapacity cDNA Reverse Transcription Kit (Applied Biosystems, Abingdon, UK), as per manufacturer's instructions.

Transcriptase reverse quantitative real time PCR (RT-qPCR) was performed using SYBR Green Mastermix. The validated assay primer mix were purchased from Bio-Rad (Hemel Hempstead, UK). The Unique Assay ID of Bio-Rad primers mix assays were: S100ß (qRnoCED0002640); ENO2 (qRnoCED0001449); GRIA1 (qRnoCID0008894); GFAP (qRnoCED0005713).

The reactions contained $25 \mathrm{ng}$ of $\mathrm{cDNA}, 5 \mu \mathrm{L}$ of Precision $2 X$ qPCR Mastermix SYBR green (PrimerDesign Ltd., Southampton, UK), $0.5 \mu \mathrm{L}$ of primer mix assay and nuclease free water to a complete $10 \mu \mathrm{L}$ final volume. All reactions were made in duplicates and a no template control were run in the same plate in the LightClycler ${ }^{\circledR} 480$ (Roche Diagnostics, Burgess Hill, UK). The conditions of the running were as follows; enzyme activation at $95^{\circ} \mathrm{C}$ for $10 \mathrm{~min}, 40 \mathrm{x}$ denaturation at $95^{\circ} \mathrm{C}$ for $15 \mathrm{~s}$ and data collection at $60{ }^{\circ} \mathrm{C}$ for $1 \mathrm{~min}$, followed by melt curve. The relative quantification was calculated by the $\Delta \Delta \mathrm{Ct}$ method and expressed as fold-change [66]. GAPDH expression and the control group were used for normalization as the housekeeping gene and the calibrator, respectively.

\subsection{EV Isolation:}

EVs fractions were isolated from platelet-free plasma by differential centrifugation. Briefly, plasma was diluted in PBS (Gibco, Abingdon, UK) and ultracentrifugation at $120,000 \times g$ for $120 \mathrm{~min}$ at $4{ }^{\circ} \mathrm{C}$ was used to pellet the EVs using the Beckman Coulter (Brea, CA, USA) Type 70 Ti rotor. The pellet was then resuspended in PBS. The EV pellets were stored at $-80^{\circ} \mathrm{C}$ until further use. 


\subsection{Nanoparticle Tracking Analysis (NTA):}

EV size and quantity were determined using ZetaView Nanoparticle Tracker (Particle Metrix, Cambridge, UK) with the ZetaView software (8.04.02 SP2). The calibration of the instrument was performed using a nanosphere size standard $(100 \mathrm{~nm}$ diameter; Thermo Fisher Scientific, Abingdon, UK). Instrument pre-acquisition parameters were set to a temperature of $23^{\circ} \mathrm{C}$, sensitivity of 80 , frame rate of 30 frames per second (fps), shutter speed of 100, and a laser pulse duration equal to that of shutter duration. Post-acquisition parameters were set to a minimum brightness of 25, maximum size of 1000 pixels, and a minimum size of 5 pixels. Each sample was diluted 1:3000 and $1 \mathrm{~mL}$ of diluted EVs was injected into the sample-carrier cell and the particle count was measured at eleven positions, with two cycles of reading per position. Samples were read in duplicate. The cell was washed with PBS (Gibco, Abingdon, UK) after every sample. The mean size and concentration of EVs/mL $( \pm \mathrm{SEM})$ was calculated for each group.

\subsection{Transmission Electron Microscopy (TEM)}

TEM imaging was performed to validate the presence of EVs in pellets EVs isolated from platelet-free plasma. The pellet of EVs was resuspended in PBS and diluted 1:10 in PBS for optimum imaging, applied freshly in discharged carbon Formvar $3 \mathrm{~mm} 200$ Mesh Cu Grids (AgarScientific, Stansted, UK) for $2 \mathrm{~min}$ before being blotted with filter paper. Grids were stained with $2 \%$ uranyl acetate for $10 \mathrm{~s}$, blotted and air dried. Grids were imaged in a FEI Tecnai 12 TEM at $12 \mathrm{kV}$ (GAtan OneView CMOS camera, Pleasanton, CA, USA).

\subsection{Western Blotting}

Western blotting was used to confirm the presence of EVs in our samples. Briefly, proteins were resolved by $8-16 \%$ Precise Protein Gel SDS-polyacrylamide (Thermo Fisher Scientific, Abingdon, UK) electrophoresis and transferred using a semi-dry system to polyvinylidene difluoride membranes (PVDF) (Bio-Rad, Hemel Hempstead, UK). After blocking, blots were incubated overnight with the primary polyclonal antibody TSG101 (1:250; $5 \%$ bovine serum albumin, 4A10 Ab83 Abcam, Cambridge, UK) (marker of presence of EVs). Detection was performed with the appropriate IgG horseradish peroxidase-linked secondary antibody (1:5000; Cell Signaling Technology Danvers, MA, USA). Image analysis was performed using a G:BOX imaging system (Syngene, Cambridge, UK).

\subsection{Relative Quantification of Gene Expression in Plasma EVs}

Total RNA was extracted from EVs fractions using the miRNeasy Mini Kit (Qiagen, Abingdon, UK) as per manufacturer's instructions. Eluted RNA was checked for quantity and quality using a NanoDrop 1000 spectrophotometer (Thermo Fisher Scientific, Abingdon, UK). Samples with 260/280 and 260/230 ratios > 2 were converted to cDNA using the High-Capacity cDNA Reverse Transcription Kit (Applied Biosystems, Abingdon, UK), as per manufacturer's instructions. RT-qPCR was performed was described in 4.6. for S100 $\beta$ (qRnoCED0002640) (Bio-Rad, Hemel Hempstead, UK).

\subsection{Statistical Analysis}

Data was analyzed using either unpaired Student- $t$ tests or two-way ANOVA to compare groups in Graphpad Prism 6 software (San Diego, CA, USA). The data has been presented as mean \pm SEM. $p$-value was set at $<0.05$ for all analyses.

Author Contributions: Conceptualization, M.E.C.-L. and G.d.P.A.; methodology, G.d.P.A., M.A.-O., M.S.-B., J.Z., L.I., L.M.P.F., C.S.F.M., D.A. and M.E.C.-L.; software, G.d.P.A. and M.A.-O.; writingoriginal draft preparation, G.d.P.A.; writing-review and editing, G.d.P.A., M.A.-O., M.S.-B., J.Z., L.I., L.M.P.F., C.S.F.M., D.A. and M.E.C.-L.; supervision, M.E.C.-L. and D.A.; funding acquisition, M.E.C.-L. and D.A. All authors have read and agreed to the published version of the manuscript. 
Funding: This research was supported by the Conselho Nacional de Desenvolvimento Científico e Tecnológico (CNPq, grant numbers 27724/2018-2 and 307564/2017-7) and Coordenação de Aperfeiçoamento de Pessoal de Nível Superior (CAPES, grant number 88887.200500/2018-00). Fellowships of G.d.P.A (POS-DOC - 88881.172137/2018-01) and of M.A.-O. and L.I. were founded by CAPES and Productivity Award of M.E.C.-L. was founded by CNPq.

Institutional Review Board Statement: The study was conducted according to the guidelines of the NIH, and approved by the Committee for Ethics in Experimental Research with Animals of the Universidade Federal do Pará (CEUA 8343070518).

Data Availability Statement: All data of this study can be requested to the corresponding author M.E.C.-L. (ecrespo@ufpa.br or maria.elena.crespo.lopez@gmail.com).

Acknowledgments: G.d.P.A.: M.A.-O., and L.I. would like to thank CAPES for their fellowships. M.E.C.-L. would like to thank $\mathrm{CNPq}$ for her recognition as highly productive researcher. Authors also thanks reviewers for their valuable help to improve this work.

Conflicts of Interest: The authors declare no conflict of interest. The funders had no role in the design of the study; in the collection, analyses, or interpretation of data; in the writing of the manuscript; or in the decision to publish the results.

\section{References}

1. WHO. Mercury and Health. Available online: https://www.who.int/news-room/fact-sheets/detail/mercury-and-health (accessed on 20 August 2021).

2. Crespo-Lopez, M.E.; Augusto-Oliveira, M.; Lopes-Araujo, A.; Santos-Sacramento, L.; Yuki Takeda, P.; Macchi, B.M.; do Nascimento, J.L.M.; Maia, C.S.F.; Lima, R.R.; Arrifano, G.P. Mercury: What can we learn from the Amazon? Environ. Int. 2021, 146, 106223. [CrossRef]

3. Arrifano, G.P.F.; Martin-Doimeadios, R.C.R.; Jimenez-Moreno, M.; Ramirez-Mateos, V.; da Silva, N.F.S.; Souza-Monteiro, J.R.; Augusto-Oliveira, M.; Paraense, R.S.O.; Macchi, B.M.; do Nascimento, J.L.M.; et al. Large-scale projects in the amazon and human exposure to mercury: The case-study of the Tucurui Dam. Ecotoxicol. Environ. Saf. 2018, 147, 299-305. [CrossRef]

4. Arrifano, G.P.F.; Martin-Doimeadios, R.C.R.; Jimenez-Moreno, M.; Fernandez-Trujillo, S.; Augusto-Oliveira, M.; Souza-Monteiro, J.R.; Macchi, B.M.; Alvarez-Leite, J.I.; do Nascimento, J.L.M.; Amador, M.T.; et al. Genetic Susceptibility to Neurodegeneration in Amazon: Apolipoprotein E Genotyping in Vulnerable Populations Exposed to Mercury. Front. Genet. 2018, 9, 285. [CrossRef]

5. Rodriguez Martin-Doimeadios, R.C.; Berzas Nevado, J.J.; Guzman Bernardo, F.J.; Jimenez Moreno, M.; Arrifano, G.P.; Herculano, A.M.; do Nascimento, J.L.; Crespo-Lopez, M.E. Comparative study of mercury speciation in commercial fishes of the Brazilian Amazon. Environ. Sci. Pollut. Res. Int. 2014, 21, 7466-7479. [CrossRef] [PubMed]

6. Machado, C.L.R.; Crespo-Lopez, M.E.; Augusto-Oliveira, M.; Arrifano, G.d.P.; Macchi, B.d.M.; Lopes-Araújo, A.; SantosSacramento, L.; Souza-Monteiro, J.R.; Alvarez-Leite, J.I.; Souza, C.B.A.d. Eating in the Amazon: Nutritional Status of the Riverine Populations and Possible Nudge Interventions. Foods 2021, 10, 1015. [CrossRef] [PubMed]

7. Ekino, S.; Susa, M.; Ninomiya, T.; Imamura, K.; Kitamura, T. Minamata disease revisited: An update on the acute and chronic manifestations of methyl mercury poisoning. J. Neurol. Sci. 2007, 262, 131-144. [CrossRef] [PubMed]

8. Santos-Sacramento, L.; Arrifano, G.P.; Lopes-Araujo, A.; Augusto-Oliveira, M.; Albuquerque-Santos, R.; Takeda, P.Y.; SouzaMonteiro, J.R.; Macchi, B.M.; do Nascimento, J.L.M.; Lima, R.R.; et al. Human neurotoxicity of mercury in the Amazon: A scoping review with insights and critical considerations. Ecotoxicol. Environ. Saf. 2021, 208, 111686. [CrossRef] [PubMed]

9. Shao, Y.; Yamamoto, M.; Figeys, D.; Ning, Z.; Chan, H.M. Proteomic Analysis of Cerebellum in Common Marmoset Exposed to Methylmercury. Toxicol. Sci. 2015, 146, 43-51. [CrossRef]

10. Korogi, Y.; Takahashi, M.; Shinzato, J.; Okajima, T. MR findings in seven patients with organic mercury poisoning (Minamata disease). AJNR. Am. J. Neuroradiol. 1994, 15, 1575-1578.

11. Jackson, A.C. Chronic Neurological Disease Due to Methylmercury Poisoning. Can. J. Neurol. Sci. J. Can. Sci. Neurol. 2018, 45, 620-623. [CrossRef]

12. Augusto-Oliveira, M.A.; Arrifano, G.P.; Lopes-Araujo, A.; Santos-Sacramento, L.; Takeda, P.Y.; Anthony, D.C.; Malva, J.O.; Crespo-Lopez, M.E. What Do Microglia Really Do in Healthy Adult Brain? Cells 2019, 8, 1293. [CrossRef]

13. Augusto-Oliveira, M.; Arrifano, G.P.; Delage, C.I.; Tremblay, M.-È.; Crespo-Lopez, M.E.; Verkhratsky, A. Plasticity of microglia. Biol. Rev. 2021. [CrossRef]

14. Ni, M.; Li, X.; Rocha, J.B.; Farina, M.; Aschner, M. Glia and methylmercury neurotoxicity. J. Toxicol. Environ. Health Part A 2012, 75, 1091-1101. [CrossRef]

15. Arrifano, G.P.; Augusto-Oliveira, M.; Souza-Monteiro, J.R.; Macchi, B.M.; Lima, R.R.; Sunol, C.; do Nascimento, J.L.M.; CrespoLopez, M.E. Revisiting Astrocytic Roles in Methylmercury Intoxication. Mol. Neurobiol. 2021. [CrossRef] [PubMed]

16. Rice, K.M.; Walker, E.M., Jr.; Wu, M.; Gillette, C.; Blough, E.R. Environmental mercury and its toxic effects. J. Prev. Med. Public Health 2014, 47, 74-83. [CrossRef] [PubMed] 
17. Yilmaz, F.M.; Yilmaz, H.; Tutkun, E.; Uysal, S.; Carman, K.B.; Dilber, C.; Ercan, M. Serum biochemical markers of central nerve system damage in children with acute elemental mercury intoxication. Clin. Toxicol. 2014, 52, 32-38. [CrossRef] [PubMed]

18. Arrifano, G.; Del Carmen Rodriguez Martin-Doimeadios, R.; Jimenez-Moreno, M.; Augusto-Oliveira, M.; Rogerio Souza-Monteiro, J.; Paraense, R.; Rodrigues Machado, C.; Farina, M.; Macchi, B.; do Nascimento, J.; et al. Assessing mercury intoxication in isolated/remote populations: Increased S100B mRNA in blood in exposed riverine inhabitants of the Amazon. Neurotoxicology 2018, 68, 151-158. [CrossRef]

19. Branco, V.; Caito, S.; Farina, M.; Teixeira da Rocha, J.; Aschner, M.; Carvalho, C. Biomarkers of mercury toxicity: Past, present, and future trends. J. Toxicol. Environ. Health Part B Crit. Rev. 2017, 20, 119-154. [CrossRef]

20. Augusto-Oliveira, M.; de Paula Arrifano, G.; Lopes-Araújo, A.; Santos-Sacramento, L.; Lima, R.R.; Lamers, M.L.; Le Blond, J.; Crespo-Lopez, M.E. Salivary biomarkers and neuropsychological outcomes: A non-invasive approach to investigate pollutantsassociated neurotoxicity and its effects on cognition in vulnerable populations. Environ. Res. 2021. [CrossRef]

21. Van Eldik, L.J.; Wainwright, M.S. The Janus face of glial-derived S100B: Beneficial and detrimental functions in the brain. Restor. Neurol. Neurosci. 2003, 21, 97-108.

22. Marostica, G.; Gelibter, S.; Gironi, M.; Nigro, A.; Furlan, R. Extracellular Vesicles in Neuroinflammation. Front. Cell Dev. Biol. 2021, 8, 623039. [CrossRef]

23. Van Niel, G.; D'Angelo, G.; Raposo, G. Shedding light on the cell biology of extracellular vesicles. Nat. Rev. Mol. Cell Biol. 2018, 19, 213-228. [CrossRef]

24. Zhao, S.; Sheng, S.; Wang, Y.; Ding, L.; Xu, X.; Xia, X.; Zheng, J.C. Astrocyte-derived extracellular vesicles: A double-edged sword in central nervous system disorders. Neurosci. Biobehav. Rev. 2021, 125, 148-159. [CrossRef]

25. Xia, X.; Wang, Y.; Huang, Y.; Zhang, H.; Lu, H.; Zheng, J.C. Exosomal miRNAs in central nervous system diseases: Biomarkers, pathological mediators, protective factors and therapeutic agents. Prog. Neurobiol. 2019, 183, 101694. [CrossRef]

26. Goetzl, E.J.; Mustapic, M.; Kapogiannis, D.; Eitan, E.; Lobach, I.V.; Goetzl, L.; Schwartz, J.B.; Miller, B.L. Cargo proteins of plasma astrocyte-derived exosomes in Alzheimer's disease. FASEB J. Off. Publ. Fed. Am. Soc. Exp. Biol. 2016, 30, 3853-3859. [CrossRef]

27. Goetzl, E.J.; Boxer, A.; Schwartz, J.B.; Abner, E.L.; Petersen, R.C.; Miller, B.L.; Kapogiannis, D. Altered lysosomal proteins in neural-derived plasma exosomes in preclinical Alzheimer disease. Neurology 2015, 85, 40-47. [CrossRef] [PubMed]

28. Goetzl, E.J.; Schwartz, J.B.; Abner, E.L.; Jicha, G.A.; Kapogiannis, D. High complement levels in astrocyte-derived exosomes of Alzheimer disease. Ann. Neurol. 2018, 83, 544-552. [CrossRef] [PubMed]

29. Bottino, C.; Vazquez, M.; Devesa, V.; Laforenza, U. Impaired aquaporins expression in the gastrointestinal tract of rat after mercury exposure. J. Appl. Toxicol. JAT 2016, 36, 113-120. [CrossRef] [PubMed]

30. Oliveira, A.N.; Pinheiro, A.M.; Belém-Filho, I.J.A.; Fernandes, L.M.P.; Cartágenes, S.C.; Ribera, P.C.; Fontes-Júnior, E.A.; CrespoLopez, M.E.; Monteiro, M.C.; Lima, M.O.; et al. Unravelling motor behaviour hallmarks in intoxicated adolescents: Methylmercury subtoxic-dose exposure and binge ethanol intake paradigm in rats. Environ. Sci. Pollut. Res. Int. 2018, 25, 21937-21948. [CrossRef]

31. Bellum, S.; Thuett, K.A.; Bawa, B.; Abbott, L.C. The effect of methylmercury exposure on behavior and cerebellar granule cell physiology in aged mice. J. Appl. Toxicol. JAT 2013, 33, 959-969. [CrossRef]

32. Bourdineaud, J.P.; Laclau, M.; Maury-Brachet, R.; Gonzalez, P.; Baudrimont, M.; Mesmer-Dudons, N.; Fujimura, M.; Marighetto, A.; Godefroy, D.; Rostene, W.; et al. Effects of methylmercury contained in a diet mimicking the Wayana Amerindians contamination through fish consumption: Mercury accumulation, metallothionein induction, gene expression variations, and role of the chemokine CCL2. Int. J. Mol. Sci. 2012, 13, 7710-7738. [CrossRef]

33. Crespo-Lopez, M.E.; Soares, E.S.; Macchi, B.M.; Santos-Sacramento, L.; Takeda, P.Y.; Lopes-Araujo, A.; Paraense, R.S.O.; SouzaMonteiro, J.R.; Augusto-Oliveira, M.; Luz, D.A.; et al. Towards Therapeutic Alternatives for Mercury Neurotoxicity in the Amazon: Unraveling the Pre-Clinical Effects of the Superfruit Acai (Euterpe oleracea, Mart.) as Juice for Human Consumption. Nutrients 2019, 11, 2585. [CrossRef]

34. Farina, M.; Rocha, J.B.; Aschner, M. Mechanisms of methylmercury-induced neurotoxicity: Evidence from experimental studies. Life Sci. 2011, 89, 555-563. [CrossRef]

35. Santana, L.; Bittencourt, L.; Nascimento, P.; Fernandes, R.; Teixeira, F.; Fernandes, L.; Freitas Silva, M.; Nogueira, L.; Amado, L.; Crespo-Lopez, M.; et al. Low doses of methylmercury exposure during adulthood in rats display oxidative stress, neurodegeneration in the motor cortex and lead to impairment of motor skills. J. Trace Elem. Med. Biol. 2019, 51, 19-27. [CrossRef]

36. Takahashi, T.; Fujimura, M.; Koyama, M.; Kanazawa, M.; Usuki, F.; Nishizawa, M.; Shimohata, T. Methylmercury Causes Blood-Brain Barrier Damage in Rats via Upregulation of Vascular Endothelial Growth Factor Expression. PLoS ONE 2017, 12, e0170623. [CrossRef]

37. Roda, E.; Coccini, T.; Acerbi, D.; Castoldi, A.; Bernocchi, G.; Manzo, L. Cerebellum cholinergic muscarinic receptor (subtype-2 and -3) and cytoarchitecture after developmental exposure to methylmercury: An immunohistochemical study in rat. J. Chem. Neuroanat. 2008, 35, 285-294. [CrossRef]

38. Farina, M.; Aschner, M. Methylmercury-Induced Neurotoxicity: Focus on Pro-oxidative Events and Related Consequences. Adv. Neurobiol. 2017, 18, 267-286. [CrossRef]

39. Aschner, M.; Yao, C.P.; Allen, J.W.; Tan, K.H. Methylmercury alters glutamate transport in astrocytes. Neurochem. Int. 2000, 37, 199-206. [CrossRef]

40. Xu, F.; Farkas, S.; Kortbeek, S.; Zhang, F.X.; Chen, L.; Zamponi, G.W.; Syed, N.I. Mercury-induced toxicity of rat cortical neurons is mediated through N-Methyl-D-Aspartate receptors. Mol. Brain 2012, 5, 30. [CrossRef] [PubMed] 
41. Van Den Bosch, L.; Van Damme, P.; Bogaert, E.; Robberecht, W. The role of excitotoxicity in the pathogenesis of amyotrophic lateral sclerosis. Biochim. Biophys. Acta 2006, 1762, 1068-1082. [CrossRef] [PubMed]

42. Chater, T.E.; Goda, Y. The role of AMPA receptors in postsynaptic mechanisms of synaptic plasticity. Front. Cell. Neurosci. 2014, 8 . [CrossRef] [PubMed]

43. Colón-Rodríguez, A.; Colón-Carrión, N.M.; Atchison, W.D. AMPA receptor contribution to methylmercury-mediated alteration of intracellular $\mathrm{Ca}^{2+}$ concentration in human induced pluripotent stem cell motor neurons. Neurotoxicology 2020, 81, 116-126. [CrossRef] [PubMed]

44. Bailey, J.M.; Colón-Rodríguez, A.; Atchison, W.D. Evaluating a Gene-Environment Interaction in Amyotrophic Lateral Sclerosis: Methylmercury Exposure and Mutated SOD1. Curr. Environ. Health Rep. 2017, 4, 200-207. [CrossRef] [PubMed]

45. Ciccarelli, R.; Di Iorio, P.; Bruno, V.; Battaglia, G.; D'Alimonte, I.; D'Onofrio, M.; Nicoletti, F.; Caciagli, F. Activation of A(1) adenosine or mGlu3 metabotropic glutamate receptors enhances the release of nerve growth factor and S-100beta protein from cultured astrocytes. Glia 1999, 27, 275-281. [CrossRef]

46. Amorini, A.M.; Lazzarino, G.; Di Pietro, V.; Signoretti, S.; Lazzarino, G.; Belli, A.; Tavazzi, B. Metabolic, enzymatic and gene involvement in cerebral glucose dysmetabolism after traumatic brain injury. Biochim. Biophys. Acta 2016, 1862, 679-687. [CrossRef] [PubMed]

47. Isgrò, M.A.; Bottoni, P.; Scatena, R. Neuron-Specific Enolase as a Biomarker: Biochemical and Clinical Aspects. Adv. Exp. Med. Biol. 2015, 867, 125-143. [CrossRef] [PubMed]

48. Haque, A.; Polcyn, R.; Matzelle, D.; Banik, N.L. New Insights into the Role of Neuron-Specific Enolase in Neuro-Inflammation, Neurodegeneration, and Neuroprotection. Brain Sci. 2018, 8, 33. [CrossRef]

49. Bylicky, M.A.; Mueller, G.P.; Day, R.M. Mechanisms of Endogenous Neuroprotective Effects of Astrocytes in Brain Injury. Oxidative Med. Cell. Longev. 2018, 2018, 6501031. [CrossRef]

50. Pekny, M.; Pekna, M. Astrocyte reactivity and reactive astrogliosis: Costs and benefits. Physiol. Rev. 2014, 94, 1077-1098. [CrossRef]

51. Sofroniew, M.V.; Vinters, H.V. Astrocytes: Biology and pathology. Acta Neuropathol. 2010, 119, 7-35. [CrossRef]

52. Augusto-Oliveira, M.; Arrifano, G.P.; Takeda, P.Y.; Lopes-Araujo, A.; Santos-Sacramento, L.; Anthony, D.C.; Verkhratsky, A.; Crespo-Lopez, M.E. Astroglia-specific contributions to the regulation of synapses, cognition and behaviour. Neurosci. Biobehav. Rev. 2020, 118, 331-357. [CrossRef] [PubMed]

53. Brozzi, F.; Arcuri, C.; Giambanco, I.; Donato, R. S100B Protein Regulates Astrocyte Shape and Migration via Interaction with Src Kinase: IMPLICATIONS FOR ASTROCYTE DEVELOPMENT, ACTIVATION, AND TUMOR GROWTH. J. Biol. Chem. 2009, 284, 8797-8811. [CrossRef] [PubMed]

54. Aschner, M.; Syversen, T.; Souza, D.O.; Rocha, J.B.; Farina, M. Involvement of glutamate and reactive oxygen species in methylmercury neurotoxicity. Braz. J. Med. Biol. Res. Rev. Bras. 2007, 40, 285-291. [CrossRef] [PubMed]

55. Couch, Y.; Akbar, N.; Roodselaar, J.; Evans, M.C.; Gardiner, C.; Sargent, I.; Romero, I.A.; Bristow, A.; Buchan, A.M.; Haughey, N.; et al. Circulating endothelial cell-derived extracellular vesicles mediate the acute phase response and sickness behaviour associated with CNS inflammation. Sci. Rep. 2017, 7, 9574. [CrossRef] [PubMed]

56. Dickens, A.M.; Tovar-Y-Romo, L.B.; Yoo, S.W.; Trout, A.L.; Bae, M.; Kanmogne, M.; Megra, B.; Williams, D.W.; Witwer, K.W.; Gacias, M.; et al. Astrocyte-shed extracellular vesicles regulate the peripheral leukocyte response to inflammatory brain lesions. Sci. Signal. 2017, 10. [CrossRef]

57. Doyle, L.M.; Wang, M.Z. Overview of Extracellular Vesicles, Their Origin, Composition, Purpose, and Methods for Exosome Isolation and Analysis. Cells 2019, 8, 727. [CrossRef] [PubMed]

58. Guha, D.; Lorenz, D.R.; Misra, V.; Chettimada, S.; Morgello, S.; Gabuzda, D. Proteomic analysis of cerebrospinal fluid extracellular vesicles reveals synaptic injury, inflammation, and stress response markers in HIV patients with cognitive impairment. J. Neuroinflamm. 2019, 16, 254. [CrossRef]

59. Yardan, T.; Erenler, A.K.; Baydin, A.; Aydin, K.; Cokluk, C. Usefulness of S100B protein in neurological disorders. JPMA J. Pak. Med. Assoc. 2011, 61, 276-281.

60. Goncalves, C.A.; Leite, M.C.; Nardin, P. Biological and methodological features of the measurement of S100B, a putative marker of brain injury. Clin. Biochem. 2008, 41, 755-763. [CrossRef]

61. Streitburger, D.P.; Arelin, K.; Kratzsch, J.; Thiery, J.; Steiner, J.; Villringer, A.; Mueller, K.; Schroeter, M.L. Validating serum S100B and neuron-specific enolase as biomarkers for the human brain-A combined serum, gene expression and MRI study. PLoS ONE 2012, 7, e43284. [CrossRef]

62. Yilmaz, S.; Karakayali, O.; Kale, E.; Akdogan, A. Could serum S100B be a predictor of neuronal damage and clinical poor outcomes associated with the use of synthetic cannabinoids? S100B to predict neuronal damage of SC in the ED. Am. J. Emerg. Med. 2017, 36, 435-441. [CrossRef] [PubMed]

63. Janas, A.M.; Sapoń, K.; Janas, T.; Stowell, M.H.; Janas, T. Exosomes and other extracellular vesicles in neural cells and neurodegenerative diseases. Biochim. Biophys. Acta 2016, 1858, 1139-1151. [CrossRef]

64. Fernandes, L.M.P.; Lopes, K.S.; Santana, L.N.S.; Fontes-Júnior, E.A.; Ribeiro, C.; Silva, M.C.F.; de Oliveira Paraense, R.S.; CrespoLópez, M.E.; Gomes, A.R.Q.; Lima, R.R.; et al. Repeated Cycles of Binge-Like Ethanol Intake in Adolescent Female Rats Induce Motor Function Impairment and Oxidative Damage in Motor Cortex and Liver, but Not in Blood. Oxidative Med. Cell. Longev. 2018, 2018, 3467531. [CrossRef] 
65. Coumans, F.A.W.; Brisson, A.R.; Buzas, E.I.; Dignat-George, F.; Drees, E.E.E.; El-Andaloussi, S.; Emanueli, C.; Gasecka, A.; Hendrix, A.; Hill, A.F.; et al. Methodological Guidelines to Study Extracellular Vesicles. Circ. Res. 2017, 120, 1632-1648. [CrossRef]

66. Livak, K.J.; Schmittgen, T.D. Analysis of relative gene expression data using real-time quantitative PCR and the 2(-Delta Delta C(T)) Method. Methods 2001, 25, 402-408. [CrossRef] [PubMed] 